ノート・ Note

\title{
$\mathrm{Nb}_{2} \mathrm{O}_{5}-\mathrm{BaO}-\mathrm{B}_{2} \mathrm{O}_{3}$ 系超高純度ガラスの吸収曲線
}

（高屈折率ガラスの着色に関する研究，第 2 報）

\author{
金 怲 勲・山 根 正 之 \\ (東京工業大学 工学部 無機材料工学科) \\ (1980 年 2 月 13 日受付)
}

\section{The Absorption Curve of Very Pure Glass of the System $\mathrm{Nb}_{2} \mathrm{O}_{5}-\mathrm{BaO}-\mathrm{B}_{2} \mathrm{O}_{3}$ \\ (Study on the Color of High Index Glass, Part 2)}

\author{
Byung-Hoon KIM and Masayuki YAMANE \\ $\left(\begin{array}{l}\text { Department of Inorganic Materials, Faculty of Engineering, } \\ \text { Tokyo Institute of Technology } \\ \text { 1-12-1, Ookayama, Meguro-ku } 152\end{array}\right)$
}

[Received February 13, 1980]

Key-words : High index glass, $\mathrm{Nb}_{2} \mathrm{O}_{5}$ containing glass, Molar extinction coefficient, Absorption edge

\section{1. 緒 論}

高屈折率ガラスにしばしばみられる黄かっ色の原因に ついて明らかにするために，著者らは鉛含有ガラスにつ いて不純物を極力除いた超高純度ガラスを作製し，その 紫外部における透過限界について先に報告した ${ }^{12}$.

本研究では鉛含有ガラスと同様に高屈折率，高分散を 与える $\mathrm{Nb}_{2} \mathrm{O}_{5}{ }^{2)}$ 含有ガラスについて超高純度ガラスを作 製し,この系のガラスの短波長透過限界について調べた ので報告する.

\section{2. 実験方法}

\section{1 試料の作製}

実験は比較的多量の $\mathrm{Nb}_{2} \mathrm{O}_{5}$ を含有し，しかも，石英 ガラス製るつぼでの溶融の可能な $\mathrm{Nb}_{2} \mathrm{O}_{5}-\mathrm{BaO}_{-}-\mathrm{B}_{2} \mathrm{O}_{3} 3$ 成分系を中心に行った. ガラスの組成を表 1 に示す.

Table 1. Composition of glass studied $(\mathrm{mol} \%)$.

\begin{tabular}{lcccccc}
\hline No. & $\mathrm{Nb}_{2} \mathrm{O}_{5}$ & $\mathrm{BaO}$ & $\mathrm{B}_{2} \mathrm{O}_{3}$ & $\mathrm{SiO}_{2}$ & $\mathrm{GeO}_{2}$ \\
\hline $\mathrm{N}-0$ & - & 30.0 & 70.0 & - & - \\
$N-0.02$ & 0.02 & 31.0 & 69.0 & - & - \\
$N-0.5$ & 0.5 & 30.5 & 69.0 & - & - \\
$N-7$ & 1.0 & 30.0 & 69.0 & - & - \\
$N-3$ & 3.0 & 30.0 & 67.0 & - & - \\
$N-5$ & 5.0 & 30.0 & 65.0 & - & - \\
$N-10$ & 10.0 & 30.0 & 60.0 & - & - \\
$N-15$ & 15.0 & 30.0 & 55.0 & - & - \\
$N S-0$ & - & 47.4 & 47.4 & 5.2 & - \\
$N G-0$ & 0 & 31.6 & 21.3 & - & 42.1 \\
$N S-5$ & 5.0 & 45.0 & 45.0 & 5.0 & - \\
$N G-5$ & 5.0 & 30.0 & 25.0 & - & 40.0 \\
\hline
\end{tabular}

$\mathrm{Nb}_{2} \mathrm{O}_{5}-\mathrm{BaO}-\mathrm{B}_{2} \mathrm{O}_{3}$ 系以外の試料 $\mathrm{NS}-5$ と $\mathrm{NG}-5$ は $\mathrm{Nb}_{2} \mathrm{O}_{5}$ の含有量が等しく母ガラスの組成が異なる場合 の紫外部吸收端を調べるため, N-0, NS-0 及び NG-0 はそれぞれの母ガラスの紫外部吸収端を調べるためのも のである.

それぞれの組成について，前報1) と同様に超高純度ガ ラスと市販試薬を用いた通常の溶融法による 2 種類のガ ラスを作り，前者は吸光度測定用に後者を屈折率測定用 にした．超高純度ガラスの原料として $\mathrm{Nb}_{2} \mathrm{O}_{5}$ の原料に はメルク社製 Optipur $\mathrm{Nb}_{2} \mathrm{O}_{5}$ を, $\mathrm{BaO}, \mathrm{B}_{2} \mathrm{O}_{3}$ 及び $\mathrm{SiO}_{2}$ の原料には多摩化学社製の光通信ファイバーガラス用の $\mathrm{BaCO}_{3}, \mathrm{H}_{3} \mathrm{BO}_{3}$ 及び $\mathrm{SiO}_{2}$ を，また $\mathrm{GeO}_{2}$ 原料には和 光純薬社製の純度 99.999999 の $\mathrm{GeO}_{2}$ をそれぞれ用い た.これらの原料の不純物のうち遷移金属元素は $\mathrm{Nb}_{2} \mathrm{O}_{5}$ 中に最も多く, Fe の含有可能最高值は約 $1 \mathrm{ppm}$ であ る. 前報 ${ }^{11}$ 実験結果によるとこの程度の量の $\mathrm{Fe}$ によ る紫外部吸収端への影響は極めて小さくほとんど実験誤 差範囲内である. そのほか可視部や近紫外部に吸収帯の ある $\mathrm{Cu}, \mathrm{Cr}, \mathrm{Mn}, \mathrm{Ni}$ 及び $\mathrm{V}$ 等の含有量はいずれも 1 ppm 以下で吸收端にほとんど影響しないと思われる.

これらの原料を用いた超高純度ガラスは透明石英ガラ スるつぼを用いて溶融し，原料調合から溶融まですべて クリーンルームの中で行った. 吸収測定用板状試料と屈 折率測定用プリズム試料の作製方法も前報 ${ }^{1)}$ と同様であ 
る.

\section{2 測 定}

吸光度の測定は島津製作所製ダブルビーム 分光 光度 計 UV-180型を用いて行い，試料の被測定部分の面積は 前報1) と同じく $2 \times 4 \mathrm{~mm}$ とした. 吸光度測定用試料と して同一組成のガラスから厚さ約 $1 \mathrm{~mm}$ と $2 \mathrm{~mm}$ の 2 枚の試料を用意した. 測定に際して, これら試料のうち $1 \mathrm{~mm}$ のものを分光光度計の参照試料部に, $2 \mathrm{~mm}$ のも を被測定試料部に入れて表面反射による損失を除いた.

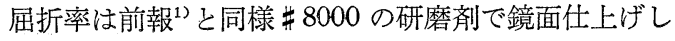
たプリズムを用いて最小偏角法によって求めた.

\section{3. 結 果}

上記測定方法による $\mathrm{Nb}_{2} \mathrm{O}_{5}-\mathrm{BaO}-\mathrm{B}_{2} \mathrm{O}_{3}$ 系超高純度ガ ラスの吸光度測定值を参照試料と被測定試料の厚みの差 が $2 \mathrm{~mm}$ の場合に換算した時の吸光度曲線を図 1 に示 す. 図中の曲線 1 と 2 は比較のために $\mathrm{Nb}_{2} \mathrm{O}_{5}$ を含有し ない試料 $\mathrm{N}-0$ (厚さ $2 \mathrm{~mm}$ ) の吸光度曲線と $\mathrm{N}-0.02$ を 厚さ $0.2 \mathrm{~mm}$ に研磨した試料の $\mathrm{Nb}$ による吸収ピーク を示したものであり,この二つの曲線は空気を参照にし て得た. 図から明らかなように $\mathrm{Nb}_{2} \mathrm{O}_{5}$ の含有量の増加 とともに紫外部吸収端が長波長側にシフトする. この系 のガラスの吸収が $207 \mathrm{~nm}$ に吸收ピークをもつ Nb の吸 収に主として支配されるものと仮定してガラスの組成及 び密度から $322 \mathrm{~nm}$ の波長における $\mathrm{Nb}$ に関するモル吸 光係数を計算した. 図 2 にその結果を示す.モル吸光係 数は $\mathrm{Nb}_{2} \mathrm{O}_{5}$ 含有量 $3 \mathrm{~mol} \%$ までは組成によらず一定 $\left(0.05 \mathrm{~mol}^{-1} \cdot \mathrm{cm}^{-1}\right)$ であるが, $5 \mathrm{~mol} \%$ 以上では $\mathrm{Nb}_{2} \mathrm{O}_{5}$ 含有量とともに増大し顕著な組成依存性が認められる.

このようなモル吸光係数の組成依存性の原因については 鉛含有ガラスにおける $\mathrm{Pb}$ の吸収ピークのシフト永と同 様に $\mathrm{Nb}$ の吸収ピークが長波長側へシフトしたことによ

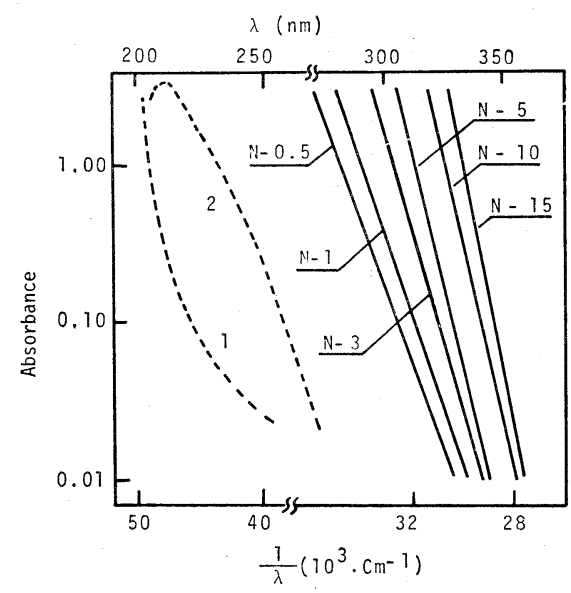

Fig. 1. Absorption curves of ultra-pure glasses of the system $\mathrm{Nb}_{2} \mathrm{O}_{5}-\mathrm{BaO}-\mathrm{B}_{2} \mathrm{O}_{3}$ (thickness : $2 \mathrm{~mm}$ ).

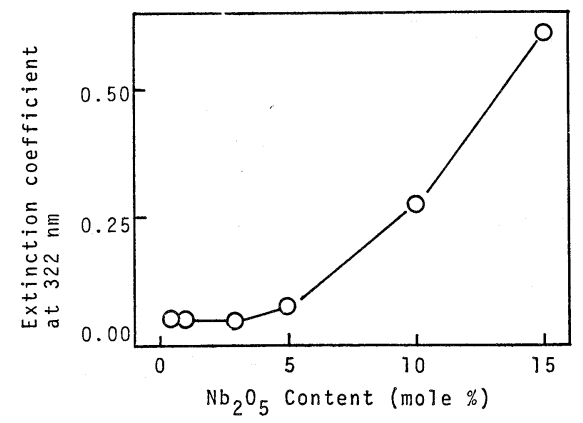

Fig. 2. Dependence of molar extinction coefficient of $\mathrm{Nb}$ on $\mathrm{Nb}_{2} \mathrm{O}_{5}$ content.

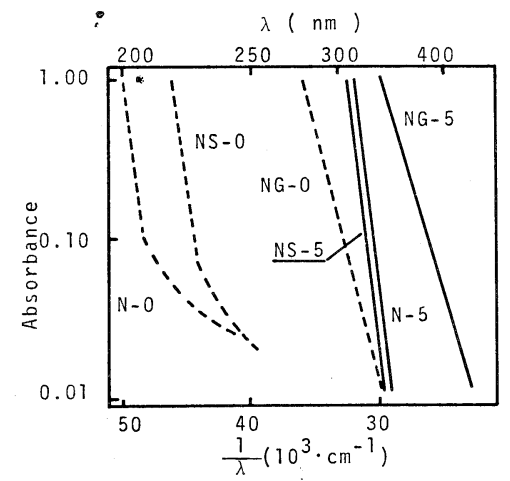

Fig. 3. Influence of glass composition on the absorption edge of $\mathrm{Nb}_{2} \mathrm{O}_{5}$ containing glass (thickness : $2 \mathrm{~mm}$ ).

Table 2. Refractive index, Abbe number and absorption edge of $\mathrm{Nb}_{2} \mathrm{O}_{5}$ containing glass.

\begin{tabular}{l|c|c|c|c|c}
\hline \multirow{2}{*}{ No. } & \multicolumn{2}{|c|}{ Refractive index } & \multirow{2}{*}{$v_{D}$} & \multicolumn{2}{l}{$\begin{array}{l}\lambda_{\text {abs. }}=1 \\
\text { (nm) }\end{array}$} \\
\cline { 2 - 4 } & ${ }^{n_{F}}$ & ${ }^{n} D$ & ${ }^{n} C$ & & \\
\hline$N-0.5$ & 1.6271 & 1.6199 & 1.6170 & 61.38 & 289 \\
$N-1$ & 1.6326 & 1.6250 & 1.6222 & 60.10 & 293 \\
$N-3$ & 1.6521 & 1.6436 & 1.6401 & 53.63 & 306 \\
$N-5$ & 1.6760 & 1.6659 & 1.6615 & 45.92 & 313 \\
$N-10$ & 1.7180 & 1.7030 & 1.6979 & 38.58 & 326 \\
$N-15$ & 1.7917 & 1.7742 & 1.7677 & 32.25 & 332 \\
NS-5 & 1.6837 & 1.6748 & 1.6703 & 50.26 & 308 \\
NG-5 & 1.8002 & 1.7865 & 1.7815 & 42.60 & 334 \\
\hline
\end{tabular}

るものか, 他の原因によるものかは現段階では明らかで はない。

図 3 には $\mathrm{Nb}_{2} \mathrm{O}_{5}$ 含有量の等しい N-5, NS-5 及び NG-5 の吸光度曲線とそれぞれの母ガラスの吸光度曲線 を示す. 吸光度が 1 になる波長 $\lambda_{\mathrm{abs}=1}$ を吸収端とする とこの波長は $\mathrm{Nb}_{2} \mathrm{O}_{5}$ 含有量が等しくても母ガラスの組 成によって異なり, 母ガラス自体の吸収端が近紫外部に ある NG-5 のそれが最も長波長側にある。

各試料の屈折率とアッベ数を表 2 に示す. $\mathrm{Nb}_{2} \mathrm{O}_{5}$ $\mathrm{BaO}-\mathrm{B}_{2} \mathrm{O}_{3} 3$ 成分系では $\mathrm{Nb}_{2} \mathrm{O}_{5}$ 含有量の増加とともに 屈折率と分散が增大している. また N-5, NS-5 及び NG-5 では NG-5 の分散が最も大きく, 全般的にはア ッべ数が小さいガラスほどその紫外部吸収端が長波長側 にある。 


\section{文献}

1）金 炳勲, 山根正之, 窯協, 88, 191 (1980).

2) S. Hirota and T. Izumitani, J. Non-Crystalline
Solids, 29, 109 (1978).

3) E.V. Smirnova, Soviet Phys. (Engl. trans.), 10, 247 (1965).

ノート・ Note

\title{
$\mathrm{B}_{2} \mathrm{O}_{3}-\mathrm{Na}_{2} \mathrm{O}$ 系のガラス化領域と液相粘度
}

\author{
大田陸夫・曽我直弘 \\ (京都大学 工学部 工業化学科) \\ (1980 年 5 月 6 日受付)
}

\section{Liquidus Viscosities and Glass-forming Regions in the $\mathrm{B}_{2} \mathrm{O}_{3}-\mathrm{Na}_{2} \mathrm{O}$ System}

\author{
Rikuo OTA and Naohiro SOGA \\ (Department of Industrial Chemistry, Faculty of Engineering, Kyoto University) \\ Yoshida, Sakyo-ku, Kyoto-shi 606
}

[Received May 6, 1980]

Key-words : $\mathrm{B}_{2} \mathrm{O}_{3}-\mathrm{Na}_{2} \mathrm{O}$ system, Liquidus viscosity, Glass formation

\section{1. 緒}

高粘度の液体は冷却したとき，ガラス化しやすいが， 低粘度の液体は失透しやすいことを我々は経験的に知っ ている1).このような観測からガラス化傾向と粘度に関 し, 次のような仮説を立て, その妥当性について検討す ることとした.

「単成分のガラス化傾向は第 1 に液相粘度の大きさに よって支配される，そして，ガラス化領域と結晶領域の 境界の組成の液相粘度（ガラス化のための臨界粘度）は 冷却速度が一定であれば，ほぼ一定である。」

本研究の目的は, この仮説の一般的な妥当性を検討す るための手順としてまず $\mathrm{B}_{2} \mathrm{O}_{3}-\mathrm{Na}_{2} \mathrm{O}$ 系を取りあげガラ ス化領域と液相粘度の関係を明らかにすることである. この系には二つのガラス化領域が存在する2)ので，それ ぞれのガラス化領域の臨界粘度を求め比較することがで きる.

\section{2. 実験方法及び結果}

\section{1 ガラス化領域}

$\mathrm{B}_{2} \mathrm{O}_{3}-\mathrm{Na}_{2} \mathrm{O}$ 系のガラス化領域を次の方法で決定した. 試薬として, 特級炭酸ソーダ $\left(\mathrm{Na}_{2} \mathrm{CO}_{3}\right)$ 及び特級酸化木 ウ素 $\left(\mathrm{B}_{2} \mathrm{O}_{3}\right)$ を用い $\mathrm{B}_{2} \mathrm{O}_{3}$ 100\% から $0 \%$ までの種々 の組成の混合物 $10 \mathrm{~g}$ を容量 $30 \mathrm{cc}$ の白金るつぼに入れ， 炭化ケイ素発熱体電気炉中で $1200^{\circ} \mathrm{C}$ の温度で 30 分間,
加熱溶融した後, るつぼを $20^{\circ} \mathrm{C}$ の水に沈め, 急冷した. るつぼの内容物は失透すると容易にガラスと区別できる ので, ガラス化の判定は肉眼で行った. ガラス化領域を 次の二つの領域に分けた. (1) ガラスのみからなる領域 を “完全ガラス化領域”，(2) 部分的に 失透したガラス 領域を“部分ガラス化領域”と名ゔけた. 完全ガラス化 領域と部分ガラス化領域の境界組成を “上限ガラス化組 成”，部分 ガラス化領域と結晶領域の境界組成を “下限 ガラス化組成”と呼ぶこととした.

$\mathrm{B}_{2} \mathrm{O}_{3}-\mathrm{Na}_{2} \mathrm{O}$ 系には，二つのガラス化が見いだされた. $\mathrm{B}_{2} \mathrm{O}_{3}=100 \sim 62 \mathrm{~mol} \%$ は完全ガラス化領域, $\mathrm{B}_{2} \mathrm{O}_{3}=62$ $\mathrm{mol} \%$ では微量の結晶が析出し始めるので, ガラス化の 上限組成である. $\mathrm{B}_{2} \mathrm{O}_{3}=61 \mathrm{~mol} \%$ ではガラス相はるつ ぼの壁の近くだけにしか見られないので, ガラス化の下 限組成である. $\mathrm{B}_{2} \mathrm{O}_{3}=62 \sim 61 \mathrm{~mol} \%$ はガラスと結晶の 混合物であり, 部分ガラス化領域である. $\mathrm{B}_{2} \mathrm{O}_{3}=61 \sim 33$ $\mathrm{mol} \%$ は結晶領域であった. $\mathrm{B}_{2} \mathrm{O}_{3}=33 \sim 28 \mathrm{~mol} \%$ は部 分ガラス化領域, $\mathrm{B}_{2} \mathrm{O}_{3}=33$ 及び $28 \mathrm{~mol} \%$ がガラス化 の下限組成である。 $\mathrm{B}_{2} \mathrm{O}_{3}$ が $28 \mathrm{~mol} \%$ 以下は再び結晶 領域となる. $1 \mathrm{~g}$ の溶融量で, 空冷条件下で決定した今 岡のガラス化領域 ${ }^{2}$ は, $\mathrm{B}_{2} \mathrm{O}_{3}=100 \sim 62 \mathrm{~mol} \%$, 及び 33.5 $\sim 28.5 \mathrm{~mol} \%$ であり, 本実験のガラス化領域と大体一致 した. 本実験のガラス化領域が今岡のガラス化領域より わずかに狭いのは，本実験の溶融量が多く，冷却速度 